\title{
Computer optics and photonics for students of laser engineering disciplines
}

\section{Zakharov}

V. P. Zakharov, "Computer optics and photonics for students of laser engineering disciplines," Proc. SPIE 9664, Ninth International Topical Meeting on Education and Training in Optics and Photonics, 96641F (24 October 2005); doi: 10.1117/12.2207771

SPIE Event: Ninth International Topical Meeting on Education and Training in Optics and Photonics, 2005, Marseille, France 


\title{
Ref ETOP087
}

\section{Computer optics and photonics for students of laser engineering disciplines}

\author{
V.P.Zakharov
}

Samara State Aerospace University, Samara, Russia

\begin{abstract}
The concept of teaching in optics and photonics for undergraduate and postgradute students of laser engineering disciplines are discussed. The designed curriculum include as fundamental knowledge on modern mathematics, physics and computer methods as up-todate industrial optical engineering software training. Distributed Web-server technology with Alpha cluster station background allow to support real-time training and teaching with a set of computer optical laboratories, which are used as a framework for most university special courses. Remote access to facilities of Russian Academy of Science make it possible to accumulate modern science achievements in optical education.
\end{abstract}

\section{Key words}

laser engineering, photonic, computer methods, scientific-educational center, optical curriculum, optics software.

\section{Summary}

The concept of teaching in optics and photonics for undergraduate and postgraduate students of laser engineering disciplines are discussed. This concept is a part of a complex educational program of Samara state aerospace university (SSAU), one of the basis Russian technical universities. SSAU pay much attention to the development of new effective methods of optical education and training. The main university objective is to achieve fast integration of modern science achievements and engineering technologies to educational practice. As a result special scientific-educational center "Computer methods in diffractive optics and imaging" was established in 2003 with financially support of Russian Federation Ministry of Education and Science, Samara Region Administration, and the American Civilian Research and Development Foundation (CRDF ProjectSA-014-02) as part of the joint Russian-American program "Basic Research and Higher Education" (BRHE). Scientificeducational center (SEC) bring together a unique network of laboratories, pulling together science and industry to achieve the transfer of knowledge and technology, and provide access to state-of-the-art equipment, highly skilled personal, conduct feasibility studies and trainings.

The designed university optical curriculum for laser engineering disciplines include as fundamental knowledge on modern mathematics, physics and computer methods as up-todate industrial optical engineering software training. The optical educational program is structured to cover the relevant topics in computer optics and photonics, from wave nature of light to ultra short pulse generation, types of lasers, lens design, computer simulations and experiences in photonics, including geometric and wave optics as well as principles of lasers and various photonics applications. Its realization is based on SEC distributed Web-server technology with Alpha cluster station background, which allow to support real-time training and teaching with a set of computer optical laboratories. These laboratories are used as a framework for most special courses: quantum electronics, applied optics, laser physics and techniques, laser optics, photonics, imaging, reflectance and fluorescence spectroscopy and others. 
Several software packages form a universal optical software environment, which is uses as a foundation in different student laboratory computer trainings and simulations of different processes (imaging, illumination, lightning, laser device modelling etc.). As a result each student may simulate any studied process, calculate optical system, plan laboratory work and then compare experimental and calculated results. Such approach makes it possible to intensify and extend the knowledge of optics and its application in many areas.

First-year students start their learning of optical software packages in courses of classic base optics from the first steps of their education in university. For example, a special animated real-time network package is used for learning Diffraction. It include own API, optical database and 3D simulation of optical laboratory, equipped with different lasers and complete set of traditional optical devices and elements. The student may select any of above virtual elements and light sources and place, combine or model either a real device or a training laboratory job environment. A real-time diffraction image is processed by dynamic layout changing and source tuning. Each step of virtual laboratory work may be logged and issued as a final laboratory report paper.

The complexity of optical software usage increases from one to another course. Starting from the third year of education university students begin training in modern professional optical software, including Lambda Research Corporation (LRS) products OSLO (optical design software) and TracePro (opto-mechanical modeling). The university syllabus of Applied Optics course was modified in order to include special lectures, concerning optical engineering software learning, especially detail analyses of computer optical methods based on LRS product demos. This course is used as a leading knowledge base in other university courses, which use OSLO and TracePro as a universal background. In particularly special exercises were designed in TracePro and OSLO software environment for modelling laser wave interaction with biological tissue, laser optical systems for industrial technology lasers, for semiconductor laser micro-optics etc. Those exercises are used in courses of Laser Physics and Technique, Imaging systems, Optical calculations of Applied Mathematics and Physics Department, Computer Optics Department and Laser Engineer speciality of Engineer Department of our university. It must be mentioned that software localization and special educational exercises plays an important role in success and progress of industrial software educational application. Such effective implication of modern software packages in university photonic and laser courses will be impossible without great efforts of our professors and lecturers, who devoted much time for software localization and issue of localized methodical literature for students.

Besides own optical network we use remote access to facilities of Russian Academy of Science (RAS), which make it possible to accumulate modern science achievements in optical education. Thus, server database engine of Institute of Atmospheric Optics of RAS is used for on-line laboratory exercises in courses of Laser remote sensing and Atmosphere optics. The on-line programs of loffe Institute of RAS are used for remote education in photonics and semiconductor lasers.

As a result after a year of training undergraduate and postgraduate students begin to use professional software in their term papers and degree thesis. In current academic year Lambda Research Corporation software was used in most annual term student papers of laser speciality and in six photonics postgraduate theses.

We also try to attach the top students to photonics scientific programs. The various approaches are used for that including annual conferences for students and young scientists, awards for the best student presentations, featuring lectures by prominent scientists from Russia and overseas. 